Article

\title{
Does Administrative Approval Impede Low-Quality Innovation? Evidence from Chinese Manufacturing Firms
}

\author{
Haiwei Jiang ${ }^{1, * \mathbb{D}}$, Shiyuan $\operatorname{Pan}^{1}$ and Xiaomeng Ren ${ }^{2}$ \\ 1 School of Economics, Zhejiang University, Hangzhou 310027, China; shiyuanpan@zju.edu.cn \\ 2 China Academy of West Region Development, Zhejiang University, Hangzhou 310058, China; \\ xiaomengren@zju.edu.cn \\ * Correspondence: haiweijiang@zju.edu.cn
}

Received: 15 February 2020; Accepted: 29 February 2020; Published: 3 March 2020

check for updates

\begin{abstract}
Sustainable economic development is tightly connected to substantial innovation which can be improved by reducing low-quality innovation. This paper constructs a theoretical framework to present the ultimate relationship between administrative approval and sustainability. In order to verify the research hypotheses, we define the dormant patents whose patent rights are terminated due to non-payment of renewal fees to measure the low-quality innovation of Chinese manufacturing firms. By using the merged firm-level data between 1998 and 2007 and collected information on whether a city establishes the administrative approval center (AAC), and employing a difference-in-difference (DID) approach, we identify the impacts of administrative approval and firms' low-quality innovation. First, the results reveal that administrative approval reduces the firms' low-quality innovation. Second, administrative approval has a smaller impact on the low-quality innovation for state-owned enterprises (SOE). Third, three mechanisms are uncovered through which administrative approval impedes low-quality innovation: enhancing market competition, changing the direction of innovation, and optimizing research and development (R\&D) investment strategy.
\end{abstract}

Keywords: administrative approval; low-quality innovation; dormant patents; sustainable economic development

\section{Introduction}

Since the reform and opening-up in 1978, China's economic development has made remarkable achievements. Since then, the average annual GDP growth rate is over $9 \%$, and China has now become the second largest economy in the world. During this period, productivity growth through technological innovation has been the main source of economic growth [1]. However, China's productivity is still only $13 \%$ of the U.S. level at present, which means that China still has plenty of room for productivity and economic growth through innovation [2].

The literature converges to the fact that sustainable economic development cannot be achieved without innovation $[3,4]$. In the era of the planned economy, China's scientific research activities are mainly dominated by research institutions in the public sector, and firms in the private sector have no incentive to innovate due to the monopoly of the market [5]. Facing the downward pressure on sustainable economic development, China realized the crucial role of innovation, and the government has carried out much effective work in speeding up innovation activities, such as attracting foreign investment with advanced technology and providing subsidies to innovative firms [6]. These reforms by the Chinese government have greatly improved the innovation capability and performance of domestic firms. From 1995 to 2010, the total number of patent applications grew at an average annual 
rate of nearly 20\% (Figure A1), which is called patent explosion [7]. In 2011, China surpassed the United States in total patent filings, becoming the country with the largest number of patent applications in the world. However, these policies that aim at stimulating innovation do not work well consistently, especially for substantial innovation which really makes a difference to the sustainable economic growth. An increasing number of firms tried to be identified as an innovative firm by the government through conducting low-quality innovation since there are no specific rules on distinguishing the quality of innovation. As a result, the low-quality of innovation in China shows a similar pattern, increasing significantly (Figure A1). In order to address this problem, the government set up the administrative approval center (AAC) in major cities to hinder low-quality innovation. It witnessed a trend that the proportion of low-quality innovation has been decreasing since the mid-1990s. We wonder whether there is a certain relationship between the AAC and low-quality innovation. The above discussion is the concern of this study in terms of the reality.

As for the points of theoretical research and academic research, the topic on government intervention and innovation is also arguable. There could be market failures in firms' innovation caused by externalities and incomplete information [8]. To reduce the distortion, the government regulates the process of innovation through policy guidance, and use the "visible hand" to make up for market failures [9]. While these policies could increase the quantity of innovation, they may not promote the quality of innovation to a certain extent, even hindering innovation quality. For example, due to asymmetric information, it is difficult for the government to verify whether the innovation is actually carried out after receiving subsidies [10]. Additionally, the intervention would induce rent seeking behaviors in collusion between the business and the government, which affects innovation activities $[11,12]$. On the whole, the existing studies imply that the impacts of government administration on innovation are ambiguous.

In China, the government regulates the quality of innovation activities mainly through administrative approval which is supposed to reject the low-quality patent applications. The goal of this work is to investigate the impacts of administrative approval on low-quality innovation. Also, this paper provides the ultimate relationship between administrative approval and sustainability theoretically with the conceptual framework. To start with, this paper puts forward the research hypotheses based on the existing literature. Then, we calculate the number of dormant patents of Chinese manufacturing firms to measure the low-quality innovation. We use whether the city in which the firm locates establishes the AAC as an experiment policy to measure the administrative approval of the government, and employ a difference-in-difference (DID) approach to identify the impacts of administrative approval on low-quality innovation.

The remainder of this paper is organized as follows: Section 2 introduces the related literature, constructs the theoretical framework, and proposes the research hypotheses. Section 3 introduces the data and the measurement. Section 4 presents the setting of the empirical model and reports the regression results and tests. Section 5 reports the robustness tests, heterogeneity tests, and examines the mechanisms. Section 6 concludes.

\section{Theory and Hypotheses Development}

\subsection{Related Literature}

This study relates to two major strands of literature in terms of the relationship between administrative approval and sustainability.

To start with, a bunch of papers study the reform of administrative approval, and how administrative approval affects innovation in China. First, some research explores how government regulations affect China's economic development. Based on the data of the World Bank's survey of China's major cities, it is shown that government administration is the mechanism that affects economic development. Government administration sets the barriers of outward foreign investment, and the improvement of governance benefits firms to invest abroad [13]. Government administration improves 
the business environment mainly through the mechanism of breaking through the department barriers, and thus is beneficial to economic development [14]. Second, some research further discusses the role of Chinese administrative approval. The reform of the administrative approval system is the breakthrough to transform the government functions and adjust the relationship between the government and the market. Some studies suggest that the reform of administrative approval has a significant positive impact on economic growth by reducing firms' transaction costs $[15,16]$. The improvement of administrative approval increases the firm entry rate by about $2 \%-25 \%$, which can effectively stimulate market vitality. The implementation of administrative approval reform enhances the efficiency of inter-departmental coordination, then facilitates the firms to enter the market [17]. Also, establishing AAC can effectively promote government transparency and enhance the effectiveness of government management [18]. Third, some papers investigate the impacts of government administration on firms' innovation [19]. Some studies find that Chinese public firms motivated by industrial policies only significantly increase the number of non-invention patent applications, that is, they only pursue the quantity of innovation but ignoring the quality of innovation [20]. Administration among cities in China creates innovation bubbles and further distorts the role of innovation, reducing the quality of firms' innovation [21,22]. Government decentralization as one of reform functions of administrative approval is able to improve the innovation capability of firms. Reducing the policy burden, inputting the innovation resources and other policies are important for government administration affecting firms' innovation $[23,24]$. The AAC establishment could reduce the system transaction cost to a certain extent, promote firms' research and development (R\&D) activities and affect technological innovation [25].

Additionally, modern economics holds that innovation is the key driver of sustainable economic growth $[3,4,26]$. First, some theoretical models explain the reasons and mechanism of innovation's contribution to sustainable economic growth [27-29]. Second, a large number of empirical studies provide the evidence supporting the view that innovation contributes greatly to sustainability among different countries [30-32]. Third, it should be particularly noted that the conception of the above innovation refers to substantial innovation which is caused by a new combination of endogenous production factors [33]. This new combination of production factors means that the previous combinations are discarded because of obsolescence. This process of creative destruction is considered as substantial innovation, which plays a vital role for sustainable economic development in the academic sense $[29,34]$. However, low-quality innovation cannot perform in a similar way as substantial innovation to improve productivity. In contrast, the low efficiency of research resources caused by low-quality innovation is harmful to sustainability to some extent.

\subsection{Theoretical Framework}

By reviewing the above related literature, we find that most of the existing studies separately discuss the relationship between administrative approval and innovation, and the relationship between innovation and economic development. In order to further reveal the relationship between administrative approval and sustainable economic development, we construct a theoretical framework (Figure 1) in which all the factors are connected tightly and logically.

In the theoretical framework, we shed light on how low-quality innovation exerts impacts on sustainable economic development. The existing studies already show that substantial innovation promotes sustainable economic development significantly. As a type of innovation, low-quality innovation is likely to waste research resources, which is disadvantageous for substantial innovation. That is, substantial innovation would increase with more inputs of research resources by impeding low-quality innovation, which improves sustainable economic development eventually.

More importantly, this paper demonstrates the effects and mechanisms of administrative approval on low-quality innovation theoretically and empirically. We find that administrative approval impedes firms' low-quality innovation through three channels, namely strengthening the market competition, changing the innovation direction, and optimizing R\&D strategy. Overall, the theoretical framework presents the logical link between our study and sustainability. 
Combined with the existing studies and the conceptual framework, this paper mainly contributes to the literature on four grounds: First, to our knowledge, we are the first to define dormant patent according to the Patent Law of China, and use it to measure Chinese firms' low-quality innovation. Second, we identify the causal effects of administrative approval on firms' low-quality innovation. Third, we examine the possible mechanisms of administrative approval affecting low-quality innovation. Fourth, we construct a theoretical framework demonstrating the ultimate relationship between administrative approval and sustainability with all the factors included.

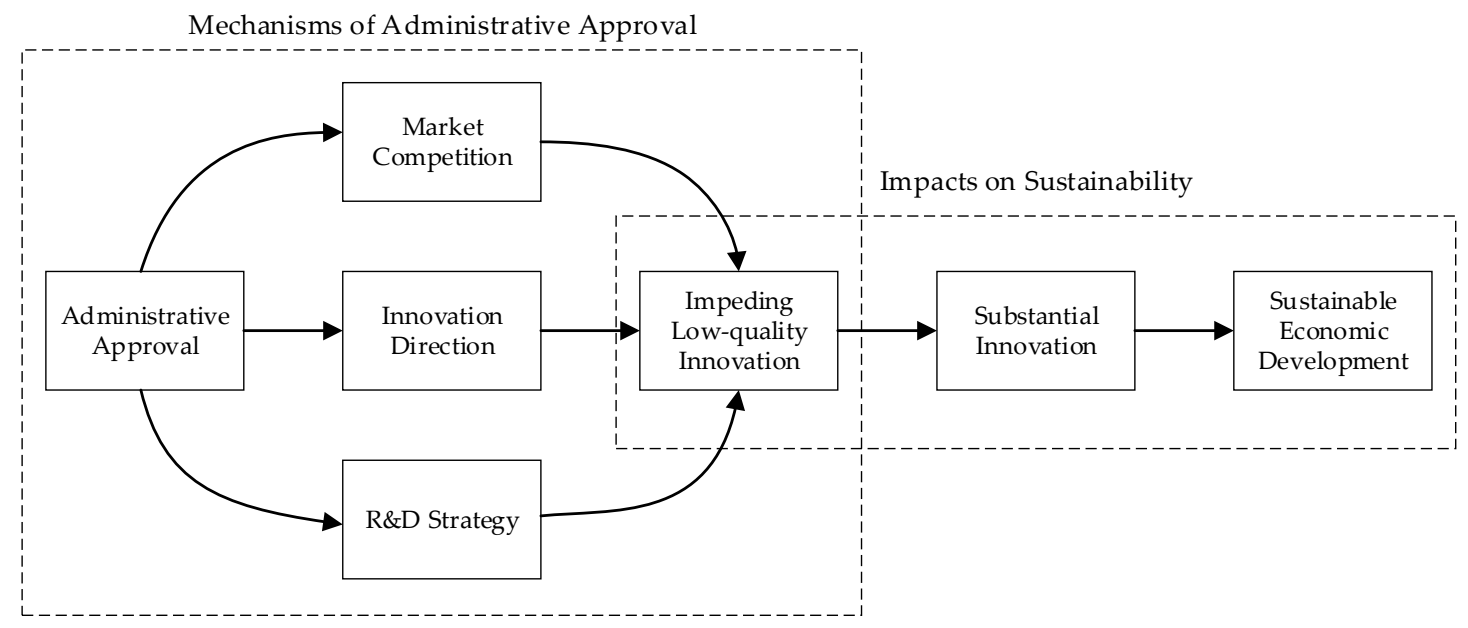

Figure 1. Theoretical framework.

\subsection{Research Hypotheses}

The above literature and theoretical framework show that one of the goals of establishing the $\mathrm{AAC}$ is to regulate the process of firms' innovation and urge firms to make technological progress by improving the structure of innovation, boosting sustainable economic development ultimately. In addition to theoretical specification, this paper proposes and tests several research hypotheses to provide empirical evidence. In the following parts of this paper, we focus on the empirical analysis on the effects and mechanisms of administrative approval on low-quality innovation.

As a powerful administration method, administrative approval controls the quality of innovation with a consistent and uniform standard among different regions [18]. Instead of identifying high-quality innovation, administrative approval always considers the patent applications above the criteria as substantial innovation. Simultaneously, it manages to rule out low-quality innovation that cannot reach the criteria $[15,23]$. It is reasonable that administrative approval is likely to reduce firms' low-quality innovation.

Hypothesis 1: Administrative approval reduces firms' low-quality innovation.

The strength of administration varies among different regions due to the difference of development phases. The developed cities in China try to push themselves forward comprehensively at most aspects like ecological progress, cultural and ethical progress, while the underdeveloped cities only care about economic development. Generally, the latter is unwilling to implement the policies which might affect regional innovation [22]. As a consequence, these certain differences in enforcement may result in different administration outcomes.

Hypothesis 2: The stronger administrative approval intensity causes less low-quality innovation.

As a result of cooperation across administration departments, the establishment of AAC increases the transparency of the approval process and reduces the approval time for events, which greatly 
increases the efficiency of the administrative approval. One-stop administrative approval service reduces the cost of firms entering the market, increases the entry rate and intensifies the market competition [17]. In a competitive market, with low-quality innovation, it is hard to bring about excess profits [35]. In other words, strengthening administrative approval in the competitive market will crowd out low-quality innovation since the low-quality innovators are unprofitable.

Hypothesis 3: Administrative approval reduces firms' low-quality innovation through enhancing market competition.

In fact, the government establishing the AAC not only regulates firms' patent applications, but is also like to set a target of innovation for firms directly. For instance, The Thirteenth Five-Year Plan in China sets a goal of innovation that the number of invention patents (a type of high-quality patents) per 10,000 population should increase from 6.3 to 12 by 2020 . Obviously, the target encourages the innovative firms to improve the structure of innovation, including decreasing the proportion of low-quality innovation. Additionally, firms have to allocate R\&D more efficiently across different R\&D types to gain profits by innovation since the AAC establishment brings in a higher level of marketization [36]. To achieve the targets, firms need to change their direction of innovation, and cut off low-quality innovation.

Hypothesis 4: Administrative approval reduces firms' low-quality innovation through changing the direction of innovation.

As regulated more strictly by the government due to the AAC establishment, firms cannot operate discretionarily. In contrary, regulations reduce firms' short-sighted behaviors, optimize investment strategy such as turning to make more long-term R\&D investment, which is more likely not to conduct low-quality innovation [37]. Only by doing that, can these firms obtain the surplus profits of innovation. That is, in a long period, firms will reduce producing low-quality innovation.

Hypothesis 5: Administrative approval reduces firms' low-quality innovation through optimizing RED investment strategy.

\section{Data and Measurement}

\subsection{Data}

\subsubsection{Firm-Level Panel Data}

The firm-level panel data of this article is from the Annual Survey of Industrial Firms (ASIF), conducted by the National Bureau of Statistics of China (NBS) for the 1998-2007 period. This survey covers all of state-owned enterprises (SOE) and non-SOE with annual sales over 5 million RMB. The number of firms covered in the surveys varies from approximately 149,000 to approximately 313,000 . firms in this data account for around 95\% of total Chinese industrial output and $98 \%$ of total Chinese industrial exports [38], spanning 37 2-digit manufacturing industries and 31 provinces or province-equivalent municipal cities. There are more than 100 variables in this data, including the basic information for each surveyed firm, such as its identification number, location code, industry affiliation, ownership structure, and the financial and operational information extracted from accounting statements, such as sales, employment, materials, fixed assets, and total wage bill. For our study, we need precise industry information about our sample firms. In 2003, a new classification system for industry codes (GB/T 4754-2002) was adopted in China to replace the old classification system (GB/T 4754-1994) that had been used from 1995 to 2002. We use the concordance table to achieve consistency in the industry codes over our entire sample period (1998-2007) [39]. 


\subsubsection{China Patent Database}

China Patent Database includes all patents filed with the State Intellectual Property Office (SIPO). We have data on all the patents registered in SIPO between 1985 and 2016, including about 6.77 million patents for inventions, 6.26 million patents for utility models and 4.17 million patents for designs. The data contains the patent information, the applicant information and the patent rights information corresponding to each patent. The patent information contains the name of the patent, the patent number, the time of application, the public announcement number, the public announcement date, and the international patent classification (IPC). The applicant information contains the name, address, postcode, country or province of the patent applicant. The patent rights information contains the name, priority, agent, agency, and citation of the patent designer.

\subsubsection{Data Matching}

We carry out the matching project between ASIF and Chinese Patent Database in several steps based on a reliable matching methodology [40]. The matching steps are reported in Appendix B. After matching procedures, we merge the patent data to ASIF at firm-year level.

\subsubsection{City Statistics}

We retrieve city-level characteristics of around 300 cities for each year over the period 1998-2007 from the China City Statistical Yearbook published by the Chinese National Bureau of Statistics. It documents more than 300 city statistics of economic and social development, including population, employment, labor force, comprehensive economy, agriculture development, industry development, fixed assets investment, utilization of foreign capital, education, transportation, and so on.

\subsubsection{Data of Administrative Approval Center}

This study uses whether a city establishes the AAC to measure the variation in administrative approval. The establishment of the AAC is a direct result of the Chinese administrative approval reform, which aims to centralize the independent approval departments in space, promote the cooperative work, and thus strengthen the administrative approval [41]. Our data contain information on the AAC establishment in more than 300 cities [17]. There are four variables: a dummy variable indicates whether the AAC was established in the city, the year of the AAC establishment, the number of stationed departments of administrative approval, and the number of items of administrative approval.

\subsection{Measurement}

\subsubsection{Low-Quality Innovation}

So far, there is still not a uniform definition of low-quality innovation in academic research. Inactive patents are generally regarded as dormant patents and are used to be a proxy for low-quality innovations [42]. The existing literature believes that the longer the patent rights last, the higher the value of the patent [43-46]. According to the Patent Law of China, the patentees are obligated to pay renewal fees annually within the period of validity of the patent rights since the patents are granted. In fact, the renewal fees of patents are considerable expenditures for firms if the patents are low-quality and valueless. That is, the patentees are very likely to refuse to pay the renewal fees if a patent cannot bring the innovative profits due to the low-quality problem.

Patents being terminated means they no longer enjoy all the patent rights. That is, these patents become dormant after the date of termination. Thus, patents whose patent rights are terminated due to non-payment of renewal fees have short survival time and own low commercial values. We regard these dormant patents as low-quality innovation. Specifically, we mark a patent in the China Patent Database with the status of "Renewal fees unpaid, patent rights are terminated" as the dormant patent, and use it to measure low-quality innovation. 


\subsubsection{Administrative Approval}

The empirical analysis uses the dummy whether the AAC was set up in a city to measure whether there is enforcement of administrative approval. Further, we measure administrative approval intensity by multiplying the number of departments of administrative approval and the number of items of administrative approval by the dummy variable, respectively.

\section{Empirical Analysis}

\subsection{Empirical Model Setting}

A standard approach that assesses the consequences of the AAC establishments is to run an ordinary least square (OLS) regression that regresses a firm's low-quality innovation on the city's AAC status and control variables. This approach, however, suffers from a few identification difficulties. First, the establishment of AAC and the firms' low-quality innovation could be driven by common characteristics that may not be observable to econometricians, which causes the omitted variable concern. Second, expected changes in firms' low-quality innovation might lead to the AAC establishment, which is the typical reverse-causality concern. Hence, the results obtained from a standard OLS regression may bias the estimation.

To establish causality of administrative approval on firms' low-quality innovation, we employ a DID approach that relies on plausible exogenous variation in administrative approval generated by the establishment of AAC during the sample period. The DID approach has several advantages of identifying our research question. First, the DID approach absorbs constant unobserved differences between the treatment group (i.e., cities with the AAC establishment) and the control group (i.e., cities without the AAC establishment). Second, the DID approach stripes out omitted time trends that are correlated with the establishment of AAC and firms' low-quality innovation. In addition, our research setting provides another advantage due to the fact that the establishment of AAC takes place at exogenously different times for different cities. Hence, this institutional feature represents multiple shocks to administrative approval and avoids a common identification difficulty faced by studies with a single shock: potential omitted variables coinciding with the shock could directly affect low-quality innovation. More than $80 \%$ of all the Chinese cities established the AAC during our sample period (Table A1).

We undertake the DID approach by estimating the following model:

$$
\text { Dormant Patent }_{\text {ict }}=\alpha+\gamma \mathrm{AAC}_{\mathrm{ct}}+\lambda^{\prime} \text { Controls }_{\mathrm{ict}}+\eta^{\prime} \text { Determinants }_{\mathrm{ct}}+\delta_{\mathrm{i}}+\delta_{\mathrm{c}}+\delta_{\mathrm{t}}+\varepsilon_{\mathrm{ict}}
$$

where $\mathrm{c}$, $\mathrm{i}$, and $\mathrm{t}$ denote the city, firm, and year, respectively. Dormant Patent $\mathrm{ict}_{\text {(Natural logarithm of }}$ one plus the number of dormant patents) is used to measure the low-quality innovation of Chinese manufacturing firms. $\mathrm{AAC}_{\mathrm{ct}}$ is the key variable of interest, which is a dummy variable that equals one if the AAC has been established by year $t$ in city $c$, and zero otherwise. The coefficient $\gamma$ captures the causal effect of the administrative approval on firms' low-quality innovation. Controls $s_{\text {ict }}$ includes several firm-level control variables that could affect firms' innovation, including output, age, ratio of capital to labor, a dummy variable indicating if a firm is an exporter, and a dummy variable indicating if a firm is an SOE. Determinants ${ }_{\mathrm{ct}}$ includes the city-level variables that affect the establishment of AAC to control the impact of these factors on dormant patents. $\delta_{i}, \delta_{c}$, and $\delta_{t}$ are firm fixed effects, city fixed effects, and year fixed effects, respectively. $\varepsilon_{\text {ict }}$ is the error term. Innovation metrics are likely to be autocorrelated over time. Thus, all of our models will allow the standard errors to have arbitrary heteroskedasticity and autocorrelation by clustering standard errors at firm level [47]. The descriptive statistics of the main variables are presented in Table A2. 


\subsection{Empirical Analysis}

Based on the benchmark model, this section first carefully characterizes the potential city-level determinants that affect the establishment of AAC. Then, estimate the baseline model and report the regression results. Further, perform several tests to bear out the baseline results.

\subsubsection{City-level Determinants of the AAC Establishment}

The city fixed effects in the benchmark model control the effects of time-invariant factors on low-quality innovation. However, there may be time-varying factors at the city level that affect the establishment of AAC, which in turn affects low-quality innovation. To solve this problem, we try to find the city-level variables that influence whether a city set up the AAC [48]. Specifically, we regress the dependent variable that whether a city established the AAC during 1998-2007 on the city's characteristics in 1998. The results are reported in Table A3. Column (1) controls the factors of economic development, including GDP (natural logarithm), and the ratio of output of the tertiary industry to GDP. Column (2) further controls the factor of foreign investment. Column (3) additionally controls the fixed asset investment, population, sales of industrial firms above designated sales. Column (4) adds the controls of the average wage and passenger volume. As shown in Columns (1)-(4), three variables, Tertiary ${ }_{\mathrm{ct}}, \mathrm{FDI}_{\mathrm{ct}}$, and $\mathrm{FA}_{\mathrm{ct}}$, have significant impacts on the establishment of AAC. In addition, Columns (5) and (6) show that dormant patents have no significant effects on the establishment of AAC, that is, the reverse causality in the model is not significant. Based on the above analysis, we include three variables, Tertiary ${ }_{\mathrm{ct}}, \mathrm{FDI}_{\mathrm{ct}}$, and $\mathrm{FA}_{\mathrm{ct}}$, in Determinants $\mathrm{st}_{\mathrm{ct}}$ to control the time-varying variables that might affect the AAC establishment.

\subsubsection{Baseline Regression Results}

We present the baseline results of estimating Equation (1) in Table 1. Column (1) only includes firm fixed effects and year fixed effects. The estimation result shows that the AAC establishment has a negative and statistically significant effect on firms' low-quality innovation at the $1 \%$ level, and the average treatment effect is $-0.46 \%$. Column (2) adds city fixed effects. The estimation result shows that the AAC establishment has a negative and statistically significant effect on firms' low-quality innovation at the $1 \%$ level, and the average treatment effect is $-0.47 \%$. Column (3) adds the firm-level control variables. The AAC establishment has a negative and statistically significant effect on firms' low-quality innovation at the $1 \%$ level, and the average treatment effect is $-0.54 \%$. Column (4) adds the city-level determinants. The estimation result shows that the AAC establishment has a negative and statistically significant effect on firms' low-quality innovation at the $1 \%$ level, and the average treatment effect is $-0.56 \%$. Taken together, these results support Hypothesis 1 that administrative approval reduces firms' low-quality innovation.

Table 1. Administrative approval and low-quality innovation.

\begin{tabular}{lcccc}
\hline & $\mathbf{( 1 )}$ & $\mathbf{( 2 )}$ & $\mathbf{( 3 )}$ & $\mathbf{( 4 )}$ \\
\hline Dependent Variable: & Dormant & Dormant & Dormant & Dormant \\
\hline AAC & $-0.0046^{* * *}$ & $-0.0047^{* * *}$ & $-0.0054^{* * *}$ & $-0.0056^{* * *}$ \\
& $(0.0008)$ & $(0.0008)$ & $(0.0008)$ & $(0.0008)$ \\
Output & & $0.0097^{* * *}$ & $0.0101^{* * *}$ \\
Capital_labor & & $(0.0004)$ & $(0.0004)$ \\
& & -0.0023 & -0.0023 \\
Age & & $(0.0020)$ & $(0.0020)$ \\
& & 0.0009 & 0.0006 \\
Exporter & & $(0.0014)$ & $(0.0016)$ \\
& & & $0.0057^{* * *}$ & $0.0057^{* * *}$ \\
\end{tabular}


Table 1. Cont.

\begin{tabular}{|c|c|c|c|c|}
\hline & (1) & (2) & (3) & (4) \\
\hline $\begin{array}{l}\text { Dependent Variable: } \\
\text { SOE }\end{array}$ & Dormant & Dormant & $\begin{array}{c}\text { Dormant } \\
-0.0036^{* * *} \\
(0.0013)\end{array}$ & $\begin{array}{c}\text { Dormant } \\
-0.0040^{* * *} \\
(0.0014)\end{array}$ \\
\hline Tertiary & & & & $\begin{array}{c}-0.0003^{* * *} \\
(0.0001)\end{array}$ \\
\hline FDI & & & & $\begin{array}{c}0.0013^{* * * *} \\
(0.0004)\end{array}$ \\
\hline FA & & & & $\begin{array}{c}-0.0033^{* * *} \\
(0.0011)\end{array}$ \\
\hline Constant & $\begin{array}{c}0.0341 * * * \\
(0.0004)\end{array}$ & $\begin{array}{c}0.0341^{* * *} \\
(0.0004)\end{array}$ & $\begin{array}{c}0.0011 \\
(0.0046)\end{array}$ & $\begin{array}{c}0.0499 * * * \\
(0.0178)\end{array}$ \\
\hline Firm FE & Yes & Yes & Yes & Yes \\
\hline Year FE & Yes & Yes & Yes & Yes \\
\hline City FE & No & Yes & Yes & Yes \\
\hline R-squared & 0.511 & 0.512 & 0.512 & 0.514 \\
\hline Observations & $1,864,694$ & $1,864,681$ & $1,864,681$ & $1,758,900$ \\
\hline
\end{tabular}

Note: Robust standard errors in parentheses are clustered by firm. ${ }^{* * *}, * *$ and ${ }^{*}$ denote significance at the $1 \%, 5 \%$, and $10 \%$ level, respectively.

\subsubsection{Pre-Treatment Trends}

The validity of a DID estimation depends on the parallel trends assumption: Absent the AAC establishment, the treated firms' low-quality innovation would have evolved in the same way as that of control firms. To address this point, we investigate the pre-trend between the treatment group and the control group. Specifically, we include a series of dummy variables in the standard regression to trace out the year-by-year effects of administrative approval on low-quality innovation. In the regressions, we add pre-reform and post-reform indicators taking on the unit value, respectively, in the year of AAC and one, two, and three years before and after the AAC establishment. The setting can test two questions: First, whether there is a significant difference in low-quality innovation between the treatment group and the control group before the AAC establishment. Second, whether the firms in cities that establish the AAC are with more low-quality innovation $[49,50]$.

The results of the parallel trends test are reported in Table 2. Columns (1)-(3) show that there is no significant difference between the treatment group and the control group before the AAC establishment. Further, administrative approval has a significant negative effect on the firms' low-quality innovation in the year and the years after the AAC establishment. The parallel trends test excludes the possibility that the difference between the treatment group and the control group change over time prior to the AAC establishment, and rejects that firms in cities which establish the AAC own more low-quality innovation. In summary, the results of Table 2 are reassuring and suggest that firms in the treated group do not show lower innovation performance before the AAC establishment.

The above analysis shows the average treatment effect of administrative approval on firms' low-quality innovation. To exploit the dynamic effect of this effect, we perform an event time analysis of the effect of administrative approval on firms' low-quality innovation. We set the experimental window to five years, and add the dummy variables before and after the AAC establishment to the benchmark model [51]. The regression coefficient of dummy variables is presented in Figure A2. The result shows that there is no significant difference between the regression coefficient and zero 1-5 years before the AAC establishment. That is, there is no significant effect of administrative approval on low-quality innovation before the AAC establishment. As for the year of the AAC establishment and 1-5 years after the AAC establishment, administrative approval has a negative impact on low-quality innovation. Further, we find that the impact of one year after the AAC establishment is the largest, suggesting that the establishment of AAC works immediately. 
Table 2. Parallel trends test.

\begin{tabular}{lccc}
\hline & $\mathbf{( 1 )}$ & $\mathbf{( 2 )}$ & $\mathbf{( 3 )}$ \\
\hline Dependent Variable: & Dormant & Dormant & Dormant \\
\hline AAC (before 3 years) & & & 0.0008 \\
& & & $(0.0012)$ \\
AAC (before 2 years) & & 0.0010 & 0.0012 \\
& & $(0.0010)$ & $(0.0012)$ \\
AAC (before 1 year) & -0.0005 & -0.0006 & -0.0005 \\
& $(0.0008)$ & $(0.0009)$ & $(0.0012)$ \\
AAC (current year) & $-0.0034^{* * *}$ & $-0.0037^{* * *}$ & $-0.0036^{* * *}$ \\
& $(0.0007)$ & $(0.0009)$ & $(0.0011)$ \\
AAC (after 1 year) & $-0.0033^{* * *}$ & $-0.0038^{* * *}$ & $-0.0037^{* * *}$ \\
& $(0.0008)$ & $(0.0009)$ & $(0.0011)$ \\
AAC (after 2 years) & & $-0.0023^{* *}$ & $-0.0023^{* *}$ \\
& & $(0.0009)$ & $(0.0011)$ \\
AAC (after 3 years) & & & -0.0004 \\
& & & $(0.0012)$ \\
\hline Firm control variables & Yes & Yes & Yes \\
City control variables & Yes & Yes & Yes \\
Firm FE & Yes & Yes & Yes \\
Year FE & Yes & Yes & Yes \\
City FE & Yes & Yes & Yes \\
R-squared & 0.514 & 0.514 & 0.514 \\
Observations & $1,758,900$ & $1,758,900$ & $1,758,900$ \\
\hline
\end{tabular}

Note: Robust standard errors in parentheses are clustered by firm. ${ }^{* * *}, * *$ and $*$ denote significance at the $1 \%, 5 \%$, and $10 \%$ level, respectively. firm control variables include Output, Capital_labor, Age, Exporter, SOE. City control variables include Tertiary, FDI, FA.

\subsubsection{Placebo Test}

In this section, we implement a placebo test to rule out the possibility that the results are purely driven by chance. In particular, we draw a random sample of 1,363,619 observations (the same number of observations in the treatment group) as the treatment group, and treat the rest of the pool the control group [52-54]. We re-estimate the benchmark model and save the coefficient of $\mathrm{AAC}_{\mathrm{ct}}$. We repeat this procedure 1000 times. Figure 2 plots the distribution of coefficients on $\mathrm{AAC}_{\mathrm{ct}}$. The actual coefficient on $\mathrm{AAC}_{\mathrm{ct}}$ is -0.0056 from Column (4) in Table 1 is far less than the mean of the distribution, and even smaller than the minimum coefficient estimate. These results indicate that our results are unlikely to be driven by chance.

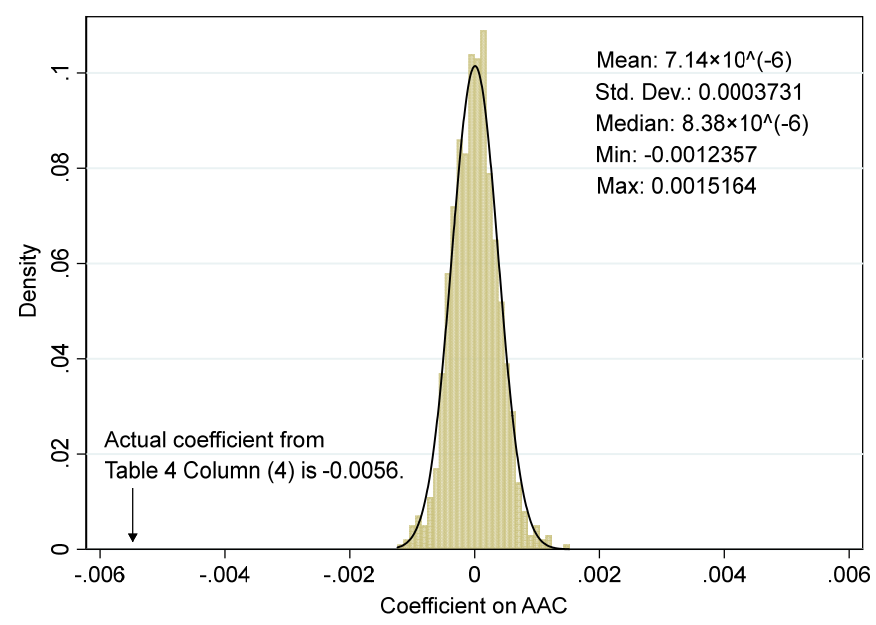

Figure 2. Placebo test. 


\subsection{Administrative Approval Intensity}

The above analysis establishes a negative causal effect of administrative approval on firms' low-quality innovation. We further examine the relationship between administrative approval intensity and firms' low-quality innovation. We apply an empirical strategy of DID, with multiple treatments at different times with different intensity in the various cities. By employing the number of departments of administrative approval and the number of items of administrative approval, we are able to measure administrative approval intensity. Specifically, we multiply the number of departments of administrative approval and the number of items of administrative approval by the dummy variable $\mathrm{AAC}_{\mathrm{ct}}$, respectively $[55,56]$. Other settings are consistent with the benchmark model. The regression results are reported in Table 3, which shows that the administrative approval intensity (the number of departments of administrative approval), $\mathrm{AAC} \_\mathrm{dpt}_{\mathrm{ct}}$, and the administrative approval intensity (the number of items of administrative approval), AAC_item $\mathrm{ct}$, both have negative and statistically significant effects on firms' low-quality innovation at the $1 \%$ level. The estimation results support the research Hypothesis 2 that the stronger administrative approval intensity leads to less low-quality innovation among firms.

Table 3. Administrative approval intensity.

\begin{tabular}{lcc}
\hline & $\mathbf{( 1 )}$ & (2) \\
\hline Dependent Variable: & Dormant & Dormant \\
\hline AAC_dpt & $-0.0904^{* * *}$ & \\
AAC_item & $(0.0168)$ & $-0.0068^{* * *}$ \\
& & $(0.0019)$ \\
\hline Firm control variables & & Yes \\
City control variables & Yes & Yes \\
Firm FE & Yes & Yes \\
Year FE & Yes & Yes \\
City FE & Yes & Yes \\
R-squared & Yes & 0.514 \\
Observations & 0.514 & $1,758,900$ \\
\hline
\end{tabular}

Note: Robust standard errors in parentheses are clustered by firm. ${ }^{* * *},{ }^{* *}$ and ${ }^{*}$ denote significance at the $1 \%, 5 \%$, and $10 \%$ level, respectively. firm control variables include Output, Capital_labor, Age, Exporter, SOE. City control variables include Tertiary, FDI, FA.

\section{Robustness Tests, Heterogeneity Effects, and Mechanisms}

\subsection{Robustness Tests}

First, the standard errors in baseline regressions are clustered at the firm level. As the interest of regressor is a city-level variable, we employ two-way clustered standard errors by clustering the standard errors at both firm and city level to mitigate the concern regarding the presence of residual correlation in both firm and city dimensions [57]. The estimation results reported in Columns (1)-(3) of Table 4 remain robust.

Second, subsidy from the Chinese government to firms catalyzes their innovation to some extent [58]. To control the influence, we control the subsidies received by firms (Nature logarithm of one plus the amount of subsidy). The estimation results reported in Columns (4)-(6) of Table 4 show that government subsidies do increase firms' low-quality innovation. Further, we find that the effects of administrative approval on low-quality innovation are still robust.

Third, patent counts vary over time and across technology classification. To adjust the low-quality innovation measure which may be partially informative, we scale the measure by IPC 1-digit class and year [59]. Specifically,

$$
\text { Scaled Dormant } \mathrm{ict}_{\mathrm{k}}=\sum_{\mathrm{k}}^{\mathrm{M}} \frac{\mathrm{n}_{\mathrm{ikct}}}{\sum_{\mathrm{c}}^{\mathrm{H}} \mathrm{N}_{\mathrm{kct}}}
$$


where $\mathrm{k}$ denotes 1-digit IPC class, $\mathrm{M}$ is the set of all 1-digit IPC classes, and $\mathrm{H}$ is the set of all cities in the sample. $n_{i k c t}$ measures the number of dormant patents of firm $i$ in IPC class $k$ in city $c$ in year $t$. $\mathrm{N}_{\mathrm{kct}}$ is the number of all dormant patents filed in IPC class $\mathrm{k}$ in city c in year $\mathrm{t}$.

We then use the scaled measure as the dependent variable and re-estimate the benchmark model. The estimation results reported in Columns (7)-(9) of Table 4 still back up the baseline results.

Table 4. Robustness tests.

\begin{tabular}{|c|c|c|c|c|c|c|c|c|c|}
\hline & (1) & (2) & (3) & (4) & (5) & (6) & (7) & (8) & (9) \\
\hline $\begin{array}{l}\text { Dependent } \\
\text { Variable: }\end{array}$ & Dormant & Dormant & Dormant & Dormant & Dormant & Dormant & $\begin{array}{l}\text { Scaled } \\
\text { Dormant }\end{array}$ & $\begin{array}{l}\text { Scaled } \\
\text { Dormant }\end{array}$ & $\begin{array}{l}\text { Scaled } \\
\text { Dormant }\end{array}$ \\
\hline \multirow[t]{2}{*}{$\mathrm{AAC}$} & $\underset{* * *}{-0.0056}$ & & & $\underset{* * *}{-0.0056}$ & & & $-\underset{* * *}{0.0026}$ & & \\
\hline & $(0.0014)$ & & & $(0.0008)$ & & & $(0.0005)$ & & \\
\hline \multirow{2}{*}{ AAC_dpt } & & -0.0904 & & & $-\underset{* * *}{-0.0912}$ & & & $-\underset{* * *}{-0.0436}$ & \\
\hline & & $(0.0272)$ & & & $(0.0168)$ & & & $(0.0096)$ & \\
\hline \multirow{2}{*}{ AAC_item } & & & $-\underset{* *}{0.0068}$ & & & -0.0070 & & & $-\underset{* * *}{-0.0033}$ \\
\hline & & & $(0.0030)$ & & & $(0.0019)$ & & & $(0.0011)$ \\
\hline \multirow[t]{2}{*}{ Subsidy } & & & & $\underset{* * *}{0.0021}$ & $\underset{* * *}{0.0021}$ & $\underset{* * *}{0.0021}$ & & & \\
\hline & & & & $(0.0002)$ & $(0.0002)$ & $(0.0002)$ & & & \\
\hline $\begin{array}{l}\text { Firm control } \\
\text { variables }\end{array}$ & Yes & Yes & Yes & Yes & Yes & Yes & Yes & Yes & Yes \\
\hline $\begin{array}{l}\text { City control } \\
\text { variables }\end{array}$ & Yes & Yes & Yes & Yes & Yes & Yes & Yes & Yes & Yes \\
\hline Firm FE & Yes & Yes & Yes & Yes & Yes & Yes & Yes & Yes & Yes \\
\hline Year FE & Yes & Yes & Yes & Yes & Yes & Yes & Yes & Yes & Yes \\
\hline City FE & Yes & Yes & Yes & Yes & Yes & Yes & Yes & Yes & Yes \\
\hline R-squared & 0.514 & 0.514 & 0.514 & 0.514 & 0.514 & 0.514 & 0.533 & 0.533 & 0.533 \\
\hline Observations & $1,758,900$ & $1,758,900$ & $1,758,900$ & $1,758,900$ & $1,758,900$ & $1,758,900$ & $1,758,900$ & $1,758,900$ & $1,758,900$ \\
\hline
\end{tabular}

Note: Robust standard errors in parentheses in Columns (1)-(3) are clustered by firm and city. Robust standard errors in parentheses in Columns (4)-(9) are clustered by firm. ${ }^{* * *},{ }^{* *}$ and ${ }^{*}$ denote significance at the $1 \%, 5 \%$, and $10 \%$ level, respectively. firm control variables include Output, Capital_labor, Age, Exporter, SOE. City control variables include Tertiary, FDI, FA.

\subsection{Heterogeneity Effects}

The fact that administrative approval is dominated by the government is likely to cause different impacts among firms with different ownership [60]. SOE have much closer connections to the government since they are wholly or partly possessed by the government. To investigate the heterogeneous effect of ownership, we multiply the regressor of interest by the dummy variable, $\mathrm{SOE}_{i c t}$, then employing the triple difference model (DDD) to estimate. The results are reported in Columns (1)-(3) of Table A4. We find that the impacts of administrative approval are still negative and statistically significant. The coefficients of interaction terms are positive and statistically significant, demonstrating that the ownership of SOE attenuates the negative effects of administrative approval. The results show that administrative approval has smaller effects on low-quality innovation for SOE.

Motivated by the fact that the foreign investment enjoys preferential policies enforced by the government [61], we guess that the impacts of administrative approval on low-quality innovation might be different between domestic firms and FIE. Similarly, we multiply the regressor of interest by the dummy variable, FIE $_{\text {ict }}$, and then estimate the regression model. The results are reported in Columns (4)-(6) of Table A4. The impacts of administrative approval on firms' low-quality innovation remain. However, there is no significant difference between the domestic firms and FIE. To explain the results, we consider that in order to attract foreign investment, the local governments would give preferential policies to FIE no matter how efficient they are. However, these benefits received by FIE only influencing the establishment of firms, but are not likely to exert a significant impact on the subsequent behaviors such as carrying out innovation activities. 


\subsection{Mechanisms}

After solidly establishing that administrative approval causes negative effects on firms' low-quality innovation, we further explore the plausible underlying mechanisms that cause the effects. It is of course challenging to provide definite proof, and hence our tests are only suggestive.

\subsubsection{Enhancing Market Competition}

As mentioned above, the stronger administrative approval is likely to reduce the cost of entry for firms, provide incentives for potential entrants to enter the market and thereby enhance market competition. Therefore, it can be an important mechanism for administrative approval to affect firms' low-quality innovation by enhancing market competition. We construct the market competition index $[62,63]$ based on the Herfindal Indel index as follow:

$$
\text { Competition }_{i t}=1-\sum_{\mathrm{i} \in \Omega_{\mathrm{jt}}}\left(\frac{\text { Output }_{\mathrm{ijt}}}{\text { Output }_{\mathrm{jt}}}\right)^{2}
$$

where j denotes 4-digit industry according to Chinese National Economic Industry Classification, Output ${ }_{\mathrm{ijt}}$ measures the output of firm $i$ in industry $j$ in year $t$, and $\Omega_{j t}$ is the set of firms in industry $j$ in year $t$.

We then construct the interaction terms by multiplying the regressor of interest by market competition, Competition ${ }_{j t}$, to perform the tests. The estimation results are reported in Table 5. The coefficients of administrative approval are significantly positive, while the coefficients of interaction terms are significantly negative. The magnitude of these items suggests that only if the market competition is high enough, can the administrative approval affect firms' low-quality innovation negatively. The results support Hypothesis 3 that administrative approval crowds out low-quality innovation through strengthening market competition by incentivizing potential entrants to enter the market.

Table 5. Market competition.

\begin{tabular}{lccc}
\hline & $\mathbf{( 1 )}$ & $\mathbf{( 2 )}$ & $\mathbf{( 3 )}$ \\
\hline Dependent Variable: & Dormant & Dormant & Dormant \\
\hline AAC $\times$ Competition & $-0.6502^{* * *}$ & & \\
& $(0.1703)$ & $-12.1294^{* * *}$ & \\
AAC_dpt $\times$ Competition & & $(3.5112)$ & \\
AAC_item $\times$ & & & $-1.1763^{* * *}$ \\
Competition & & & $(0.3565)$ \\
AAC & $0.6429^{* * *}$ & & \\
AAC_dpt & $(0.1699)$ & $12.0069^{* * *}$ & \\
& & $(3.5041)$ & \\
AAC_item & & & $1.1663^{* * *}$ \\
& & & $(0.3559)$ \\
Competition & $0.7074^{* * *}$ & $0.6695^{* * *}$ & $0.6588^{* * *}$ \\
& $(0.1741)$ & $(0.1727)$ & $(0.1735)$ \\
\hline Firm control variables & Yes & Yes & Yes \\
City control variables & Yes & Yes & Yes \\
Firm FE & Yes & Yes & Yes \\
Year FE & Yes & Yes & Yes \\
City FE & Yes & Yes & Yes \\
R-squared & 0.514 & 0.514 & 0.514 \\
Observations & $1,758,900$ & $1,758,900$ & $1,758,900$ \\
\hline
\end{tabular}

Note: Robust standard errors in parentheses are clustered by firm. ${ }^{* * *}, * *$ and ${ }^{*}$ denote significance at the $1 \%, 5 \%$, and $10 \%$ level, respectively. firm control variables include Output, Capital_labor, Age, Exporter, SOE. City control variables include Tertiary, FDI, FA. 


\subsubsection{Changing Direction of Innovation}

The government plays a regulatory role firmly due to the AAC establishment, which might change the firms' direction of innovation. Innovation policy and approval procedure can influence the innovation direction of firms, and firms will choose between high-difficulty innovation and low-difficulty innovation under different returns $[36,64]$. Regulation may change the direction of innovation, reducing the proportion of low-quality innovation. To test this assumption, we define the direction of firm innovation as the ratio of dormant patents to all patents, Direction ${ }_{\text {ict }}$, and then use it as the dependent variable. The results reported in Table 6 show that administrative approval has a negative effect on the direction of innovation, which means administrative approval reduces the proportion of low-quality innovation. The estimation results support Hypothesis 4 that administrative approval reduces firms' low-quality innovation by changing the direction of innovation.

Table 6. Direction of innovation.

\begin{tabular}{lccc}
\hline & $\mathbf{( 1 )}$ & $\mathbf{( 2 )}$ & $\mathbf{( 3 )}$ \\
\hline Dependent variable: & Direction & Direction & Direction \\
\hline AAC & $-0.0129 * * *$ & & \\
& $(0.0030)$ & $-0.2304^{* * *}$ & \\
AAC_dpt & & $(0.0569)$ & $-0.0200^{* * *}$ \\
& & & $(0.0060)$ \\
AAC_item & & & Yes \\
& Yes & Yes & Yes \\
Firm control variables & Yes & Yes & Yes \\
City control variables & Yes & Yes & Yes \\
Firm FE & Yes & Yes & Yes \\
Year FE & Yes & Yes & 0.285 \\
City FE & 0.285 & 0.285 & $1,758,900$ \\
R-squared & $1,758,900$ & $1,758,900$ & \\
Observations & & & \\
\hline
\end{tabular}

Note: Robust standard errors in parentheses are clustered by firm. ${ }^{* * *}, * *$ and ${ }^{*}$ denote significance at the $1 \%, 5 \%$, and $10 \%$ level, respectively. firm control variables include Output, Capital_labor, Age, Exporter, SOE. City control variables include Tertiary, FDI, FA.

\subsubsection{Optimizing R\&D Investment Strategy}

Innovation is a long-term process, and requires continuous R\&D investment [65]. Especially for substantial innovation, it needs long-term R\&D investment and effective management of the R\&D process. Strict regulation, to some extent, reduces firms' short-sightedness, optimizing investment strategy, and making long-term R\&D investment. Therefore, the establishment of AAC might lead to more long-term R\&D investment, which causes less production of low-quality innovation. To test this assumption, we use long-term investment (Natural logarithm of one plus the amount of long-term investment), Long-term investment $t_{i c t}$, as the dependent variable in the regression model. The estimation results reported in Table 7 show that the establishment of AAC increases the firms' long-term investment, the coefficient from Column (3) is statistically insignificant, though. The results support Hypothesis 5 that administrative approval reduces firms' low-quality innovation through optimizing R\&D investment strategy. 
Table 7. R\&D investment strategy.

\begin{tabular}{lccc}
\hline & $(\mathbf{1})$ & $\mathbf{( 2 )}$ & $\mathbf{( 3 )}$ \\
\hline Dependent Variable: & Long-term Investment & Long-term Investment & Long-term Investment \\
\hline AAC & $0.0289^{* * *}$ & & \\
& $(0.0078)$ & $0.3309 * *$ & \\
AAC_dpt & & $(0.1651)$ & 0.0232 \\
& & & $(0.0192)$ \\
AAC_item & & & Yes \\
& Yes & Yes & Yes \\
Firm control variables & Yes & Yes & Yes \\
City control variables & Yes & Yes & Yes \\
Firm FE & Yes & Yes & Yes \\
Year FE & Yes & Yes & 0.695 \\
City FE & 0.695 & 0.695 & $1,758,343$ \\
R-squared & $1,758,343$ & $1,758,343$ & \\
Observations & & & \\
\hline
\end{tabular}

Note: Robust standard errors in parentheses are clustered by firm. ${ }^{* * *}, * *$ and ${ }^{*}$ denote significance at the $1 \%, 5 \%$, and $10 \%$ level, respectively. firm control variables include Output, Capital_labor, Age, Exporter, SOE. City control variables include Tertiary, FDI, FA.

\section{Conclusions}

In this paper, we examine the effects of administrative approval on low-quality innovation. By using a DID identification strategy and a sample of Chinese manufacturing firms between 1998 and 2007, we find: First, the regression results of the benchmark DID model support Hypothesis 1 that the administrative approval impedes firms' low-quality innovation, which is in line with the literature $[15,17,18]$. Second, the empirical analysis of the constructed indicator of administrative approval intensity confirms Hypothesis 2 that the stronger administrative approval intensity could hinder the firms' low-quality innovation to a larger extent. The robustness tests still hold the above results, taking several factors into account, including re-clustering standard errors, controlling for subsidy, adjusting measurements. Third, the heterogeneity tests show that administrative approval has smaller effects on low-quality innovation for SOE. Fourth, the paper puts forward and tests the possible mechanisms through which administrative approval reduces low-quality innovation. The tests suggest that administrative approval crows out low-quality innovation through enhancing market competition by encouraging potential entrants to enter the market, which is consistent with Hypothesis 3 . The empirical evidence confirms Hypothesis 4 that administrative approval makes firms change the direction of innovation with a lower proportion of low-quality innovation. Hypothesis 5 is also supportable by the facts that firms optimize the R\&D strategy with more long-term investment which is likely to reduce low-quality innovation. Finally, we connect all the factors in a conceptual framework to show the ultimate relationship between administrative approval and sustainability. The above empirical results support the theoretical framework that administrative approval improves sustainable economic development eventually by hindering low-quality innovation. To sum up, this work contributes to the literature both theoretically and empirically.

The view that innovation has become a revolutionary driver for sustainable development is widely accepted among scholars, industry experts, and government officials. The literature suggests that sustainable development should be addressed based on innovation-centered approaches [66]. Nevertheless, the speed of change towards a world with the sustainable development is frustratingly slow. Meeting sustainable development goals will require action on a number of fronts, including harnessing and maximizing the potential of innovation. The government has the obligation to enact and implement reforms to spur the substantial innovation to tackle the current and pressing sustainability challenges [67]. Policy reforms have been crucial in generating innovation and economic growth in China over the last 40 years. Innovation increases China's potential for catch-up growth. China's 
economy still has large opportunities for raising economic growth through innovation, reducing the existing distortions and inefficiencies in the process [68].

This paper provides important implications for public policies aiming at promoting sustainable development through substantial innovation. Speaking of catalyzing substantial innovation and optimizing innovation structure, reducing low-quality innovation as far as possible is an effective method. Our results demonstrate that administrative approval can hinder low-quality innovation. These effects are nontrivial considering that innovation has long been recognized as a key factor in sustainable economic growth. Overall, only attempting to adjust the structure of innovation and improve ability of innovation would be inefficient. Instead, we suggest these countries whose sustainable economic development increasingly rely on innovation in the future should implement powerful policies to reduce low-quality innovation together with the above methods to accelerate development speed.

The limitations of this paper reside mainly in only having explored the empirical evidence, even though our research conducted several tests to check the validity and reliability of the empirical results. Moreover, although the firm-level data we use is the most representative micro-data in China, the sample period spans from 1998 to 2007, which cannot fully reflect the recent features of this research question.

The future research could construct a theoretical model to further study this problem, which is likely to reveal the influence mechanism more accurately. We also suggest that research could explore other measurements of low-quality innovation, and expand the sample interval when the Chinese micro-data are available.

Author Contributions: Conceptualization, H.J. and S.P.; methodology and formal analysis, H.J. and X.R.; investigation and data curation, H.J. and X.R.; writing—original draft preparation, H.J.; writing-review and editing, H.J. and S.P. All authors have read and agreed to the published version of the manuscript.

Funding: This paper was supported by the National Social Science Fund of China (No. 19CJL052), and China Scholarship Council (No. 201806320024).

Conflicts of Interest: The authors declare no conflict of interest.

\section{Appendix A}

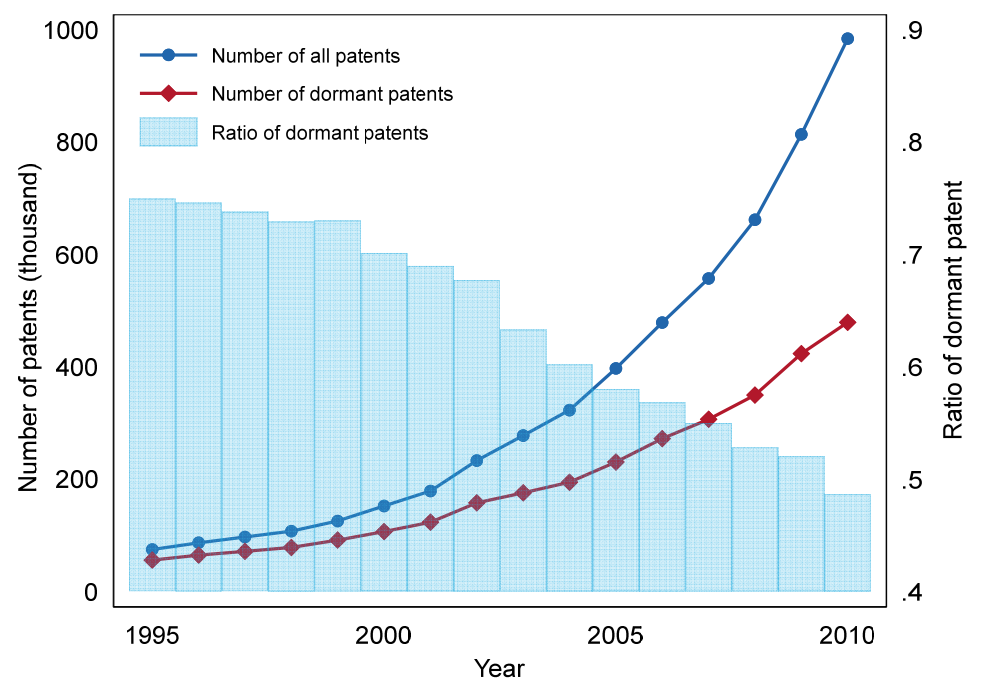

Figure A1. Trend of all patents and dormant patents. Note: The variables are manually calculated with China Patent Database. The definition of dormant patents refers to Table A2. 


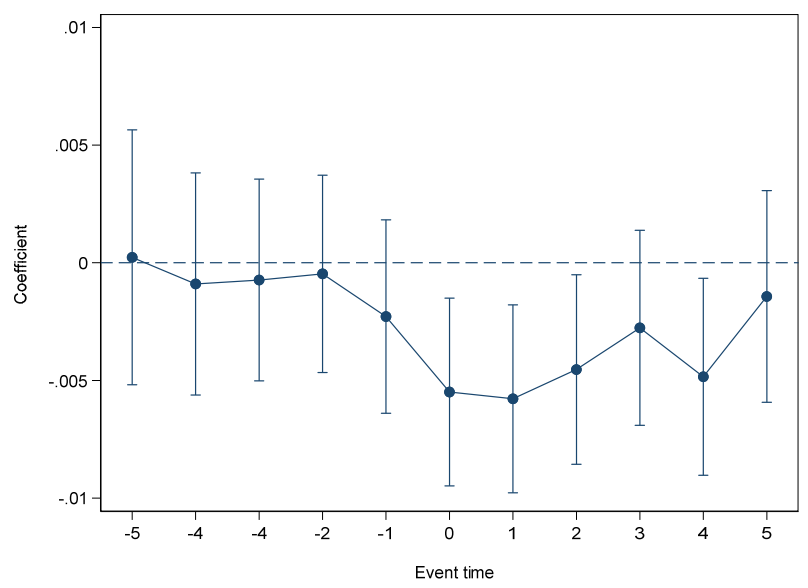

Figure A2. Dynamic effect. Note: Regression includes firm control variable, city control variables, firm fixed effects, city fixed effects and year fixed effects. The regression coefficients and $95 \%$ confidence intervals are reported.

Table A1. Statistics on years of cities establishing AAC.

\begin{tabular}{ccc}
\hline Year & Number of Cities Establishing AAC & Percentage (\%) \\
\hline Before 1998 & 3 & 0.95 \\
1998 & 1 & 0.32 \\
1999 & 2 & 0.63 \\
2000 & 17 & 5.38 \\
2001 & 57 & 18.04 \\
2002 & 75 & 23.73 \\
2003 & 28 & 8.86 \\
2004 & 26 & 8.23 \\
2005 & 25 & 7.91 \\
2006 & 11 & 3.48 \\
2007 & 10 & 3.16 \\
$2008-2015$ & 61 & 19.30 \\
\hline Total & 316 & 100 \\
\hline
\end{tabular}

Table A2. Descriptive statistics.

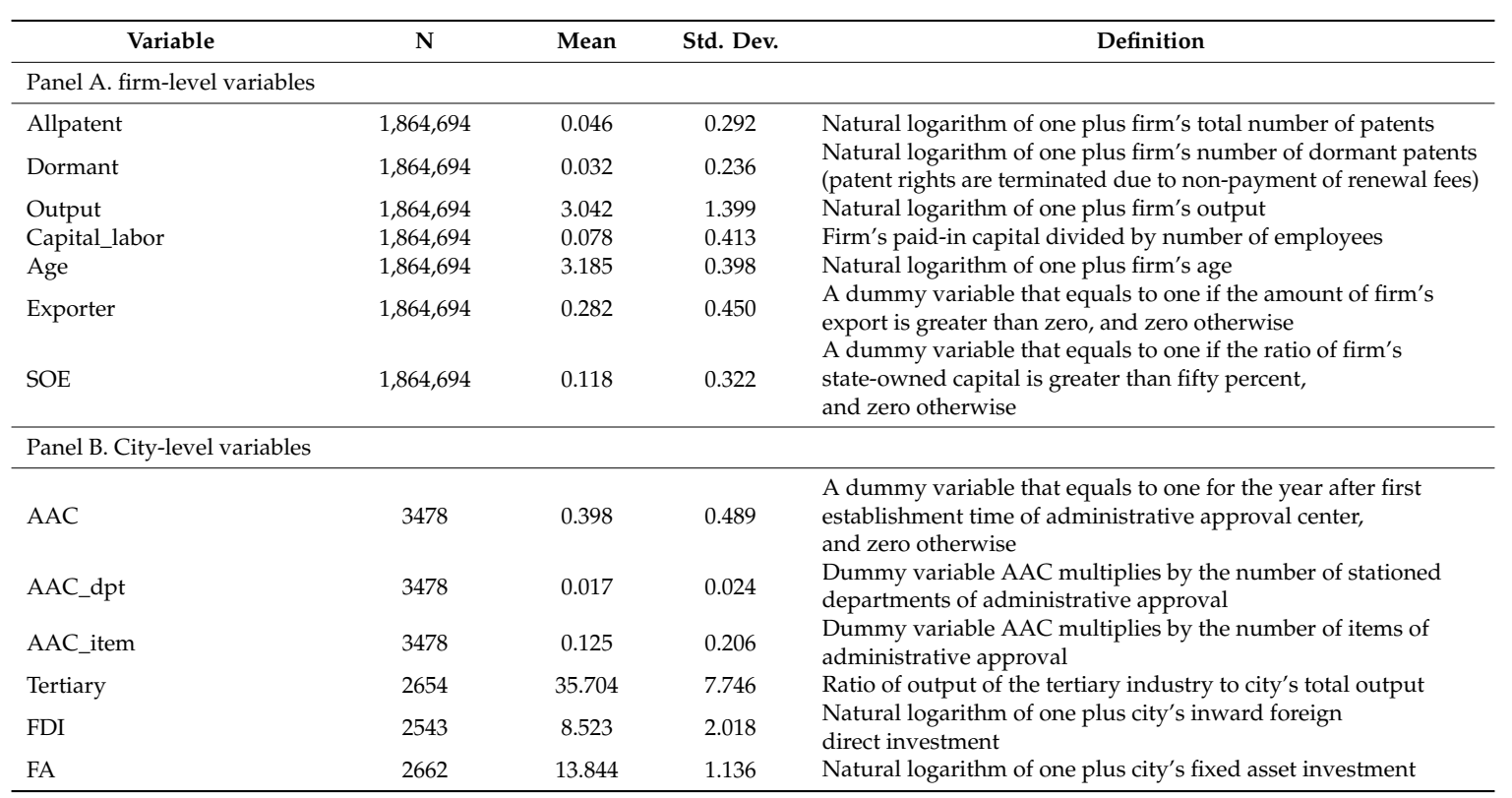


Table A3. City characteristics affecting the AAC establishment.

\begin{tabular}{|c|c|c|c|c|c|c|}
\hline & (1) & (2) & (3) & (4) & (5) & (6) \\
\hline Dependent Variable: & AAC & AAC & AAC & AAC & AAC & AAC \\
\hline Dormant & & & & & $\begin{array}{l}-0.0294 \\
(0.0196)\end{array}$ & $\begin{array}{l}-0.0207 \\
(0.0283)\end{array}$ \\
\hline GDP & $\begin{array}{l}-0.0108 \\
(0.0253)\end{array}$ & $\begin{array}{c}0.0142 \\
(0.0489)\end{array}$ & $\begin{array}{c}0.1050 \\
(0.0944)\end{array}$ & $\begin{array}{c}0.0984 \\
(0.0996)\end{array}$ & & $\begin{array}{c}0.1213 \\
(0.1028)\end{array}$ \\
\hline Tertiary & $\begin{array}{c}-0.0058^{*} \\
(0.0031)\end{array}$ & $\begin{array}{c}-0.0056^{*} \\
(0.0032)\end{array}$ & $\begin{array}{c}-0.0057 * \\
(0.0032)\end{array}$ & $\begin{array}{c}-0.0061^{*} \\
(0.0033)\end{array}$ & & $\begin{array}{c}-0.0058 \text { * } \\
(0.0035)\end{array}$ \\
\hline FDI & & $\begin{array}{c}-0.0378^{* *} \\
(0.0177)\end{array}$ & $\begin{array}{c}-0.0460 * * * \\
(0.0169)\end{array}$ & $\begin{array}{c}-0.0458^{* * *} \\
(0.0172)\end{array}$ & & $\begin{array}{c}-0.0436^{* *} \\
(0.0174)\end{array}$ \\
\hline FA & & & $\begin{array}{c}-0.1061^{* *} \\
(0.0466)\end{array}$ & $\begin{array}{c}-0.1098^{* *} \\
(0.0504)\end{array}$ & & $\begin{array}{c}-0.1161 \text { ** } \\
(0.0527)\end{array}$ \\
\hline Population & & & $\begin{array}{l}-0.0767 \\
(0.0567)\end{array}$ & $\begin{array}{l}-0.0902 \\
(0.0785)\end{array}$ & & $\begin{array}{l}-0.1001 \\
(0.0784)\end{array}$ \\
\hline Sales & & & $\begin{array}{c}0.0615 \\
(0.0590)\end{array}$ & $\begin{array}{c}0.0617 \\
(0.0581)\end{array}$ & & $\begin{array}{c}0.0682 \\
(0.0588)\end{array}$ \\
\hline Wage & & & & $\begin{array}{c}0.0015 \\
(0.1713)\end{array}$ & & $\begin{array}{l}-0.0166 \\
(0.1886)\end{array}$ \\
\hline Passenger & & & & $\begin{array}{c}0.0278 \\
(0.0358)\end{array}$ & & $\begin{array}{c}0.0352 \\
(0.0363)\end{array}$ \\
\hline Constant & $\begin{array}{c}1.1058^{* * *} \\
(0.1879)\end{array}$ & $\begin{array}{c}1.2945^{* * *} \\
(0.2330)\end{array}$ & $\begin{array}{l}1.8352 * * \\
(0.7398)\end{array}$ & $\begin{array}{c}1.7700 \\
(1.5020)\end{array}$ & $\begin{array}{c}0.9085^{* * *} \\
(0.0474)\end{array}$ & $\begin{array}{c}1.8135 \\
(1.6954)\end{array}$ \\
\hline R-squared & 0.017 & 0.071 & 0.106 & 0.108 & 0.014 & 0.118 \\
\hline Observations & 255 & 211 & 211 & 211 & 222 & 206 \\
\hline
\end{tabular}

Note: Robust standard errors in parentheses are clustered by city. ${ }^{* * *},{ }^{* *}$ and ${ }^{*}$ denote significance at the $1 \%, 5 \%$, and $10 \%$ level, respectively.

Table A4. Heterogeneity tests.

\begin{tabular}{|c|c|c|c|c|c|c|}
\hline & (1) & (2) & (3) & (4) & (5) & (6) \\
\hline Dependent Variable: & Dormant & Dormant & Dormant & Dormant & Dormant & Dormant \\
\hline $\mathrm{AAC} \times \mathrm{SOE}$ & $\begin{array}{c}0.0049^{* * *} \\
(0.0018)\end{array}$ & & & & & \\
\hline AAC_dpt $\times$ SOE & & $\begin{array}{c}0.0826^{* *} \\
(0.0378)\end{array}$ & & & & \\
\hline AAC_item $\times$ SOE & & & $\begin{array}{c}0.0085^{* *} \\
(0.0041)\end{array}$ & & & \\
\hline $\mathrm{AAC} \times \mathrm{FIE}$ & & & & $\begin{array}{c}0.0030 \\
(0.0019)\end{array}$ & & \\
\hline AAC_dpt $\times$ FIE & & & & & $\begin{array}{c}0.0552 \\
(0.0393)\end{array}$ & \\
\hline AAC_item $\times$ FIE & & & & & & $\begin{array}{c}0.0047 \\
(0.0040)\end{array}$ \\
\hline AAC & $\begin{array}{c}-0.0063 * * * \\
(0.0009)\end{array}$ & & & $\begin{array}{c}-0.0062^{* * *} \\
(0.0009)\end{array}$ & & \\
\hline AAC_dpt & & $\begin{array}{c}-0.1014 \text { *** } \\
(0.0174)\end{array}$ & & & $\begin{array}{c}-0.1007 * * * \\
(0.0173)\end{array}$ & \\
\hline AAC_item & & & $\begin{array}{c}-0.0077^{* * *} \\
(0.0020)\end{array}$ & & & $\begin{array}{c}-0.0076^{* * *} \\
(0.0020)\end{array}$ \\
\hline SOE & $\begin{array}{c}-0.0056^{* * *} \\
(0.0016)\end{array}$ & $\begin{array}{c}-0.0051 * * * \\
(0.0015)\end{array}$ & $\begin{array}{c}-0.0049^{* * *} \\
(0.0015)\end{array}$ & & & \\
\hline FIE & & & & $\begin{array}{c}0.0005 \\
(0.0021) \\
\end{array}$ & $\begin{array}{c}0.0009 \\
(0.0020) \\
\end{array}$ & $\begin{array}{c}0.0011 \\
(0.0020) \\
\end{array}$ \\
\hline Firm control variables & Yes & Yes & Yes & Yes & Yes & Yes \\
\hline City control variables & Yes & Yes & Yes & Yes & Yes & Yes \\
\hline Firm FE & Yes & Yes & Yes & Yes & Yes & Yes \\
\hline Year FE & Yes & Yes & Yes & Yes & Yes & Yes \\
\hline City FE & Yes & Yes & Yes & Yes & Yes & Yes \\
\hline R-squared & 0.514 & 0.514 & 0.514 & 0.514 & 0.514 & 0.514 \\
\hline Observations & $1,758,900$ & $1,758,900$ & $1,758,900$ & $1,758,900$ & $1,758,900$ & $1,758,900$ \\
\hline
\end{tabular}

Note: Robust standard errors in parentheses are clustered by firm. ***,** and * denote significance at the $1 \%, 5 \%$, and $10 \%$ level, respectively. firm control variables include Output, Capital_labor, Age, Exporter, SOE. City control variables include Tertiary, FDI, FA. 


\section{Appendix B}

We carry out the matching project between ASIF and Chinese Patent Database in the following several steps:

Step1. Extracting patent data

In order to improve matching efficiency, we remove patents with the following characteristics:

(1) Patents with application date outside the period of 1998-2007. (2) Patents assigned to individuals.

(3) Patents assigned to foreign firms with an address in a foreign country.

Step2. Get full name

A set of pre-processing routines are implemented to deal with patent assignee names and ASIF firm names to get standardize "full name":

(1) Trim all symbols and punctuation marks that are not letters, characters, or numbers. These include hyphen, parentheses, apostrophe, comma, bar mark, etc. We remove both half-width and full-width symbols such as \& and \&, and both half-width and full-width punctuation marks such as? and ?. (2) Convert all full-width letters into half-width ones. For example, convert B into B, C into C. (3) Convert Chinese numbers into Arabic numbers.

Step3. Get short name

Remove various designators of corporate form to obtain the so-called "short names". A set of such designators is the so-called stemming list, which includes: (1) Affix words. (2) Address words.

Step4. Exact matching

(1) Exact matching based on full name. We consider it is an exact matching pair if the full name of ASIF firm and the full name of patent assignee are identical. (2) Exact matching based on the short name. Similarly, we consider it is an exact matching pair if the short name of ASIF firm and the short name of patent assignee are identical. However, in this case, some pairs are not exactly the same. We manually check each pair of exact matching based on the short name after automatically computing matching to confirm whether it is a pair of identical firms.

Step5. Approximate matching

Our approximate matching divides the rest observations into two samples:

(1) Name containing sample: short name of ASIF firm contains the short name of patent assignee, or short name of patent assignee contains the short name of ASIF firm. It is more likely to find an identical pair in this sample. We manually check these observations to identify pairs of identical firms. (2) Name not containing sample: To conduct this work, we adopt the Levenshtein method. We calculate the Levenshtein similarity index, and manually check the observations with the index greater than 0.75 .

\section{References}

1. Jin, S.; Ma, H.; Huang, J.; Hu, R.; Rozelle, S. Productivity, efficiency and technical change: Measuring the performance of China's transforming agriculture. J. Product. Anal. 2010, 33, 191-207. [CrossRef]

2. Zhu, X. Understanding China's growth: Past, present, and future. J. Econ. Perspect. 2012, 26, 103-124. [CrossRef]

3. Romer, P.M. Endogenous technological change. J. Political Econ. 1990, 98, S71-S102. [CrossRef]

4. Acemoglu, D. Directed technical change. Rev. Econ. Stud. 2002, 69, 781-809. [CrossRef]

5. Naughton, B. China's experience with guidance planning. J. Comp. Econ. 1990, 14, 743-767. [CrossRef]

6. Liu, X.; White, S. Comparing innovation systems: A framework and application to China's transitional context. Res. Policy 2001, 30, 1091-1114. [CrossRef]

7. Hu, A.; Jefferson, G. A great wall of patents: What is behind China's recent patent explosion? J. Dev. Econ. 2009, 90, 57-68. [CrossRef]

8. Wallsten, S.J. The Effects of government-industry R\&D programs on private R\&D: The case of the small business innovation research program. RAND J. Econ. 2000, 31, 82-100. [CrossRef]

9. Jaffe, A.B. Building program evaluation into the design of public research support programs. Oxf. Rev. Econ. Policy 2002, 18, 22-34. [CrossRef] 
10. Lach, S. Do R\&D subsidies stimulate or displace private R\&D? Evidence from Israel. J. Ind. Econ. 2002, 50, 369-390. [CrossRef]

11. Shleifer, A.; Vishny, R. Politicians and firms. Q. J. Econ. 1994, 109, 995-1025. [CrossRef]

12. Dosi, G.; Marengo, L.; Pasquali, C. How much should society fuel the greed of innovators? On the relations between appropriability, opportunities and rates of innovation. Res. Policy 2006, 35, 1110-1121. [CrossRef]

13. Lu, Y.; Zhang, K. Resource dependence, government efficiency and quality of economic development. Res. Econ. Manag. 2019, 1, 3-13.

14. Liao, F. Administrative reform and business environment: Evidence from enterprises survey. Public Adm. Policy Rev. 2019, 6, 80-96.

15. Zhu, X.; Zhang, Y. Innovation and diffusion: The rise of new administrative examination and approval system in Chinese cities. Manag. World 2015, 10, 91-105.

16. Xia, J.; Liu, C. Administrative approval reform, transaction costs and China's economic growth. Manag. World 2017, 4, 47-59.

17. Bi, Q.; Chen, X.; Xu, X.; Li, S. Administrative approval reform and firm entry. Econ. Res. J. 2018, 2, 140-155.

18. Wang, Y.; Feng, X. The reform of administration approval system and firms' innovation. China Ind. Econ. 2018, 2, 24-42.

19. Xiao, W.; Han, S. The impact of changes in local government intensity on firms' going global: An empirical research based on Chinese provincial panel data for 2004-2012. J. Zhejiang Univ. (Hum. Soc. Sci.) 2016, 1, 184-199.

20. Li, W.; Zheng, M. Is it substantive innovation or strategic innovation-Impact of macroeconomic policies on micro-enterprises' innovation. Econ. Res. J. 2016, 4, 60-73.

21. Zhang, J.; Gao, D.; Xia, Y. Do patents drive economic growth in China-An explanation based on government patent subsidy policy. China Ind. Econ. 2016, 1, 83-98.

22. Long, X.; Wang, J. The cause and quality effect of patent explosion in China. J. World Econ. 2015, 6, 115-142.

23. Jiang, X. Decentralization of government and state-owned enterprises' innovation: Research based on pyramid structure of local SOEs. Manag. World 2016, 9, 120-135.

24. Lun, X.; Liu, Y.; Shen, K. The role of government and the development of medium small and micro-sized enterprise-Based on the survey data of 13 prefecture-level cities in Jiangsu province. Econ. Theory Bus. Manag. 2017, 4, 82-96.

25. He, W.; Jiang, Y.; Tang, X. Does administrative examination and approval system reform improve local government performance? A panel data analysis on Chinese 15 sub-provincial cities from 2001 to 2005. J. Public Adm. 2019, 3, 118-138.

26. Acemoglu, D. Introduction to economic growth. J. Econ. Theory 2012, 147, 545-550. [CrossRef]

27. Acemoglu, D.; Akcigit, U.; Bloom, N.; Kerr, W. Innovation, reallocation and growth. Am. Econ. Rev. 2018, 108, 3450-3491. [CrossRef]

28. Grossman, G.; Helpman, E. Quality ladders in the theory of growth. Rev. Econ. Stud. 1991, 58, 43-61. [CrossRef]

29. Aghion, P.; Howitt, P. A model of growth through creative destruction. Econometrica 1992. [CrossRef]

30. Hasan, I.; Tucci, C.L. The innovation-economic growth nexus: Global evidence. Res. Policy 2010, 39, 1264-1276. [CrossRef]

31. Maradana, R.P.; Pradhan, R.P.; Dash, S.; Gaurav, K.; Jayakumar, M.; Chatterjee, D. Does innovation promote economic growth? Evidence from European countries. J. Innov. Entrep. 2017, 6. [CrossRef]

32. Hu, A.G.Z.; Png, I.P.L. Patent rights and economic growth: Evidence from cross-country panels of manufacturing industries. Oxf. Econ. Pap. 2013, 65, 675-698. [CrossRef]

33. Schumpeter, J.A. The Theory Framework and Economic Development; Harvard University Press: Cambrige, MA, USA, 1934.

34. Garcia-Macia, D.; Hsieh, C.-T.; Klenow, P.J. How destructive is innovation? Econometrica 2019, 87, $1507-1541$. [CrossRef]

35. Shapiro, C. Premiums for high quality products as returns to reputations. Q. J. Econ. 1983, 98, 659-680. [CrossRef]

36. Chen, Y.; Pan, S.; Zhang, T. Patentability, R\&D direction, and cumulative innovation. Int. Econ. Rev. 2018, 59, 1969-1993. [CrossRef]

37. Aghion, P.; Angeletos, G.M.; Banerjee, A.; Manova, K. Volatility and growth: Credit constraints and the composition of investment. J. Monet. Econ. 2010, 57, 246-265. [CrossRef]

38. Tan, J.; Peng, M.W. Organizational slack and firm performance during economic transitions: Two studies from an emerging economy. Strateg. Manag. J. 2003, 24, 1249-1263. [CrossRef] 
39. Brandt, L.; Van Biesebroeck, J.; Zhang, Y. Creative accounting or creative destruction? Firm-level productivity growth in Chinese manufacturing. J. Dev. Econ. 2012, 97, 339-351. [CrossRef]

40. He, Z.; Tong, T.; Zhang, Y. Constructing a Chinese patent database of listed firms in China: Descriptions, lessons, and insights. J. Econ. Manag. Strateg. 2018, 27, 579-606. [CrossRef]

41. Wang, S.; Ding, Y. Defects, expansion and evolution of the administrative service center: An empirical research based on the view of administrative process reengineering. J. Public Manag. 2010, 4, 24-30.

42. Magliocca, G.N. Blackberries and barnyards: Patent trolls and the perils of innovation. Notre Dame Law Rev. 2006, 82, 1809-1838.

43. Pakes, A. Patents as options: Some estimates of the value of holding European patent stocks. Econometrica 1986, 54, 755-784. [CrossRef]

44. Schankerman, M.; Pakes, A. Estimates of the value of patent rights in European countries during the post-1950 period. Econ. J. 1986, 96, 1052-1076. [CrossRef]

45. Lanjouw, J.O. Patent protection in the shadow of infringement: Simulation estimations of patent balue. Rev. Econ. Stud. 1998, 64, 671-710. [CrossRef]

46. Cornelli, F.; Schankerman, M. Patent renewals and R\&D incentives. RAND J. Econ. 1999, 30, 197-213. [CrossRef]

47. Blanco, I.; Wehrheim, D. The bright side of financial derivatives: Options trading and firm innovation. J. Financ. Econ. 2017, 125, 99-119. [CrossRef]

48. Gentzkow, M. Television and voter turnout. Q. J. Econ. 2006, 121, 931-972. [CrossRef]

49. Alder, S.; Shao, L.; Zilibotti, F. Economic reforms and industrial policy in a panel of Chinese cities. J. Econ. Growth 2016, 21, 305-349. [CrossRef]

50. Moser, P.; Voena, A. Compulsory licensing: Evidence from the trading with the enemy act. Am. Econ. Rev. 2010, 94, 115-133. [CrossRef]

51. Priks, M. The effects of surveillance cameras on crime: Evidence from the Stockholm subway. Econ. J. 2015, 125, 289-305. [CrossRef]

52. Kogan, L.; Papanikolaou, D.; Seru, A.; Stoffman, N. Technological innovation, resource allocation, and growth. Q. J. Econ. 2017, 665-712. [CrossRef]

53. Li, P.; Lu, Y.; Wang, J. Does flattening government improve economic performance? Evidence from China. J. Dev. Econ. 2016, 123, 18-37. [CrossRef]

54. Cornaggia, J.; Mao, Y.; Tian, X.; Wolfe, B. Does banking competition affect innovation? J. Financ. Econ. 2015, 115, 189-209. [CrossRef]

55. Bertrand, M.; Duflo, E.; Mullainathan, S. How much should we trust differences-in- differences estimates? Q. J. Econ. 2004, 119, 249-275. [CrossRef]

56. Png, I. Law and innovation: Evidence from state trade secrets laws. Rev. Econ. Stat. 2017, 99, 167-179. [CrossRef]

57. Nunn, N.; Wantchekon, L. The slave trade and the origins of mistrust in Africa. Am. Econ. Rev. 2011, 101, 3221-3252. [CrossRef]

58. Fang, L.; Lerner, J.; Wu, C.; Zhang, Q. Corruption, government subsidies, and innovation: Evidence from China. NBER Work. Pap. 2018. [CrossRef]

59. Hall, B.; Jaffe, A.; Trajtenberg, M. The NBER patent citations data file: Lessons, insights and methodological tools. NBER Work. Pap. 2001. [CrossRef]

60. Xu, G.; Yano, G. How Does Anti-corruption affect corporate innovation? Evidence from recent anti-corruption efforts in China. J. Comp. Econ. 2017, 45, 498-519. [CrossRef]

61. Lu, Y.; Tao, Z.; Zhu, L. Identifying FDI spillovers. J. Int. Econ. 2017, 107, 75-90. [CrossRef]

62. Degryse, H.; Ongena, S. Distance, lending relationships, and competition. J. Financ. 2005, 60, 231-266. [CrossRef]

63. Aghion, P.; Bloom, N.; Blundell, R.; Griffith, R.; Howitt, P. Competition and innovation: An inverted-U relationship. Q. J. Econ. 2005, 120, 701-728. [CrossRef]

64. Bryan, K.; Lemus, J. The direction of innovation. J. Econ. Theory 2017, 172, 247-272. [CrossRef]

65. Mansfield, E. Academic research and industrial innovation. Res. Policy 1991, 20, 1-12. [CrossRef]

66. Silvestre, B.S.; Ţîrcă, D.M. Innovations for sustainable development: Moving toward a sustainable future. J. Clean. Prod. 2019, 208, 325-332. [CrossRef] 
67. Almeida, C.; Stepkowska, A.; Alegre, A.; Nogueira, J.M.F. Determination of trace levels of benzophenone-type ultra-violet filters in real matrices by bar adsorptive micro-extraction using selective sorbent phases. J. Chromatogr. A 2013, 1311, 1-10. [CrossRef] [PubMed]

68. Hsieh, C.-T.; Klenow, P. Misallocation and manufacturing TFP in China and India. Q. J. Econ. 2009, 124, 1403-1448. [CrossRef] 